DOI: https://doi.org/10.32839/2304-5809/2021-3-91-68

уДК 342.3

Харченко Н.П.

Національна академія внутрішніх справ

\title{
СТРАТЕГІЧНА ПРАВОТВОРЧІСТЬ: ОКРЕМІ ЗАГАЛЬНОТЕОРЕТИЧНІ АСПЕКТИ
}

Анотація. Досліджено різні позиції фахівців загальнотеоретичної та галузевих наук щодо визначення категорій «стратегічна правотворчість» та «стратегічні акти». Визначено, що стратегічна правотворчість $\epsilon$ частиною правотворчої політики держави, на яку пливають різноманітні фрактори: рівень політичної, інформаційної, економічної, культурної розвиненості країни, форма держави, географічне розташування, а також стадії історичного розвитку держави та суспільства. Запропоновано широкий та вузький підходи до трактування категорій «стратегічна правотворчість» та «стратегічні акти», а також необхідність розкриття їх взаємозв’язку з іншими суміжними категоріями за схемою від загального до конкретного: стратегічна правова політика - стратегічна правотворчість - стратегічні акти - стратегічні норми.

Ключові слова: правотворчість, стратегічна правотворчість, стратегічні акти, стратегічні норми, стратегія.

Kharchenko Natalia

National Academy of Internal Affairs

\section{STRATEGIC LAW-MAKING: SOME GENERAL THEORETICAL ASPECTS}

Summary. Considered various positions of specialists of general theoretical and branch sciences about definition of categories «strategic law-making» and "strategic acts». It is determined that strategic law-making is a part of law-making policy of the state, which is influenced by various factors: the level of political, informational, economic, cultural development of the country, state form, geographical location, and stages of historical development of state and society. It is stated that along with the category of "strategic law-making» researchers use others, which, in our opinion, do not reveal the main essence and content of this form of law-making. As well as the category of «strategic acts» is interpreted differently in the scientific community. It is noted that the use of the word "strategic» in defining the categories of «strategic law-making» and "strategic acts" reveals their main content, purpose and features. A characteristic feature of such acts and law-making is the dominance of specialized rules of law (norms-principles, norms-goals, prognostic norms, norms-definitions, etc.), which establish long-term goals and objectives of regulation and development in various public and state spheres based on monitoring a range of major problems in these areas, as well as determine the main directions, measures, institutional and functional mechanism and deadlines needed to address these issues. For the most part, the strategic acts themselves determine how long a step should be taken, they are mostly urgent. There are two main approaches to the interpretation of the category "strategic acts» and "strategic law-making»: broad and narrow. Strategic acts and strategic law-making are only part of a complex conceptual and categorical chain. We consider a constructive and promising area of scientific activity to identify and disclose the features, relationships, hierarchy of these and other related schemes from general to specific: strategic legal policy - strategic law-making - strategic acts - strategic norms. This problem is very important and actual in Ukraine.

Keywords: lawmaking, strategic lawmaking, strategic acts, strategic norms, strategy.

Постановка проблеми. Правотворчість $€$ важливим інститутом загальнотеоретичної науки, а також предметом розгляду багатьох галузевих сорер знань. Установлення конкретної системи координат, а також ї̈ якість, в межах якої фрункціонуе суспільне та державне життя конкретної країни, значно вирізняється за багатьма фракторами, зокрема від рівня політичної, інформаційної, економічної, культурної розвиненості країни, фрорми держави, наявності реальних чи потенційних загроз національній безпеці, географрічного розташування, а також конкретної стадії, на якій знаходиться держава та суспільство.

Багатоаспектна природа інститута правотворчості вимагає постійного моніторингу актуальності встановлених чи задекларованих його загальнотеоретичних засад, а також їх удосконалення відповідно до сьогодення. Найбільш значимими трансформаційними чинниками правотворчої політики України є наявність агресивної політики сусідньої країни, анексія частини території, відсутність реальної легітимної вітчизняної державної влади в окремих регіонах, а також тривала складна епідеміологічна ситуація у світі тощо.
Саме тому підвищення ефективності інституту правотворчості в Україні має бути перманентним предметом уваги як науковців у сфері розроблення та оновлення існуючих та, начебто, усталених загальнотеоретичних засад, на теоретичному рівні, а й безпосередньо суб'єктів правотворчої діяльності - на практичному рівні. Адже більшість загальнотеоретичних постулатів, правил, принципів були розроблені ще за радянських часів. Звичайно, що переважна їх кількість є актуальними й донині. Однак з'являються й нові правові френомени, явища, процеси, об'єкти та предмети дослідження, які потребують наукового й практичного осмислення та новаторського розгляду. Серед таких, зокрема, є стрімка поява та застосування правотворцем правових актів, які вирізняються дещо від «класичних» нормативно-правових актів, що упорядковують суспільні відносини у різних copepax, а визначають лише конкретні напрями розв'язання, організаційно-фрункціональний механізм реалізації відповідно до визначення стану та перспектив розвитку у чітко визначений період часу («стратегічні акти»). Попри те, що такі акти застосовувались 3 моменту становлен- 
ня України як незалежної та правової держави, слід визнати їх перманентну динаміку останніми роками в вітчизняній системі законодавства, a, отже, необхідність не лише їх визнання, а й окреслення легітимної дефініції, особливостей, ієрархії, видів, місця та ролі в системі нормативно-правових актів. Адже й донині точаться жваві наукові дискусії щодо юридичної природи таких актів: чи $є$ їх природа юридичної чи ні, чи $є$ вони правовими актами чи ні?

Аналіз останніх досліджень і публікацій. Вагоме значення у розумінні ціеї проблематики мають загальнотеоретичні праці вчених С. С. Алексєева, Д. Н. Бахраха, В. В. Копєйчикова, А. В. Малька, Н. І. Матузова, В. Д. Сорокіна, Л. В. Томаша, Л. С. Явича, які розкрили концептуальні засади інституту правотворчості в цілому. Не менш важливими для ознайомлення $є$ також загальнотеоретичні праці й сучасних фахівців теорії держави та права: С. Д. Гусарева, М. С. Кельмана, О. Г. Мурашина, О. Д. Тихомирова, М. В. Цвіка тощо, які надали нові інтерпретації загальнотеоретичним засадам інституту правотворчості. Ряд фрахівців теорії держави та права безпосередньо окреслили роль, значення, модель взаємозв'язку, ієрархію ряду стратегічних актів у забезпеченні національної та інформаційної безпеки (Ю. Є. Максименко, М. М. Пендюра, О. О. Тихомиров). Однак, слід визнати не меншу роль й галузевих наукових праць, які присвячені безпосередньо предмету даної наукової статті. Так, ще у 2003-2008 pp. було розкрито адміністративно-правові засади системи, рівні, інституційно-фрункціональний механізм, порядок розроблення та ухвалення стратегічних актів в сорері національної безпеки України (В. А. Ліпкан), а в рамках конституційного права - стратегічні акти, що ухвалюються Верховною Радою України та Президентом України, а також стратегічна правотворчість стали предметом уваги I. М. Берназюк.

Мета статті $є$ розкриття загальнотеоретичних засад щодо визначення поняття, ознак, особливостей, стратегічної правотворчості, взаємозв'язку 3 інститутом правотворчості, а також співвідношення 3 поняттям «стратегічні акти».

Виклад основного матеріалу. Уперше у вітчизняну наукову доктрину термін «стратегічна правотворчість» було введено у 2014 році I. М. Берназюк, яка запропонувала визначити її «...в двох аспектах - науково-теоретичному, як процес ініціювання, розроблення, обговорення, прийняття й реалізації стратегічних актів Верховної Ради України, Президента України та Кабінету Міністрів України, який характеризується послідовністю, строковістю, науковою обгрунтованістю, конституційно-правовою відповідальністю їі суб'єктів перед народом або відповідними представницькими органами державної влади, та практичному, як планомірну діяльність щодо ініціювання, розроблення, обговорення, прийняття та реалізації насамперед стратегічних актів Верховною Радою України, Президентом України та Кабінетом Міністрів України за участю інших суб'єктів у випадках і в порядку, встановленому законодавством України» [1, с. 10].

Однак запропонована дефініція цього терміну викликає ряд зауважень. Деякі положення є не- актуальними, адже воно було запропоноване ще у 2014 році до проведення децентралізації та появи органів місцевого самоврядування. Також слід акцентувати на посиленні ролі громадян України у визначенні основних проблем суспільного та державного життя в умовах становлення інформаційного суспільства, Так, наразі є більше можливостей заявити та реалізувати конституційне право на проведення всеукраїнських та місцевих редерендумів чи конституційне право громадян України на звернення, зокрема шляхом е-петищій.

Дещо дискусійним $є$ також теза щодо «...реалізащії стратегічних актів Верховної Ради України, Президента України та Кабінету Міністрів України» [1, с. 14], адже «правореалізація» та «правотворчість» $є$ взаємопов'язаними, однак різними правовими процесами, які різняться за метою, етапами, порядком, суб'єктами тощо. Головною метою «правореалізації є втілення правових приписів у правовій реальності, а «правотворчість» має на меті лише створення, зміну, удосконалення, скасування таких приписів.

Дослідниця також окреслила й особливості конституційно-правової природи стратегічної правотворчості: 1) це особливий вид правотворчості, який відрізняеться за фрормою відображення їі реалізації, за суб'єктами, процедурою, метою й завданнями здійснення; 2) стратегічна правотворчість $є$ основою законотворчості, оскільки задає напрям державного розвитку та визначає необхідні для розроблення законодавчі акти, тобто за своєю правовою природою стратегічний акт майже завжди є своєрідним планом законодавчої діяльності; 3) є найбільш ефективною формою політичної комунікацї між суб'єктами владних повноважень тощо [1, с. 14].

3 џого приводу зазначимо, що тези дослідниці про те, що «...стратегічна правотворчість є основою законотворчості...» [1, с. 14] чи «...за своєю правовою природою стратегічний акт майже завжди є своєрідним планом законодавчої діяльності...» [1, с. 10] значно звужуе розуміння цих категорій, адже за допомогою стратегічної правотворчості створюються не лише стратегічні акти, що закріплюються у формі законів, а й стратегічні акти, які набувають чинності у dpopмі підзаконних правових актів.

Розвиток інституту стратегічної правотворчості, а також інтенсивна поява значної кількості стратегічних актів у різних сдерах суспільного та державного життя після трагічних подій 2014 року дозволили переглянути деякі загальнотеоретичні постулати вітчизняною науковою спільнотою в цій сдері. Так, О. М. Макеєва зауважила, що стратегічна правотворчість є джерелом опосередкованого регулюючого впливу на суспільні відносини» [2, с. 85].

Згодом I. M. Берназюк переглянула дещо свою попередню позицію, зауважуючи, що стратегічна правотворчість є діяльністю суб'єктів владних повноважень щодо розробки, прийняття та реалізації стратегічних актів, яка включає в себе не тільки норми права, але і норми-принципи, норми-стратегії тощо [3, с. 10]. Хоча в підсумку майже продублювала попередне трактування стратегічної правотворчості в науково-теоретичному аспекті як «...процес розробки, прийняття 
та реалізації стратегічних актів Верховною Радою України, Президентом України та Кабінетом Міністрів України, який характеризуеться послідовністю, строковістю, науковою обгрунтованістю, політичною відповідальністю її суб'єктів перед народом» [3, с. 10]. Щодо розуміння стратегічної правотворчості у практичній площині, то дослідниця визначає їі як «...планомірну діяльність щодо розробки, прийняття та реалізації стратегічних актів Верховною Радою України, Президентом України та Кабінетом Міністрів України, за участю інших суб'єктів у випадках та порядку, встановлених законодавством України» [3, с. 10]. Недоліки цього трактування ми зазначали вище.

Попри певний прогрес дослідження вітчизняними та зарубіжними науковцями предмету наукової статті, слід визнати, що й наразі назва, юридична природа, зміст та особливості як "стратегічної правотворчості», так «стратегічних актів» $є$ різноманітними, дискусійними та здебільшого дихотомічними.

Так, О. М. Голощапов оперуе категорією «державна-правова стратегія» та надає дещо дивне визначення: «...діяльність суб'єктів, що реалізують їі, як цілеспрямовані зусилля глави держави, парламенту та уряду з якісного наповнення трьох основних ознак держави: демократичної, соціальної, правової» [4, с. 172]. Нам здається, це визначення правової політики будь-якої цивілізованої країни, вони ніяк не розкриває особливості стратегічної правотворчості.

А. М. Міронов пропонуе категорію «юридична стратегія» як специфічний вид діяльності суб'єктів правотворчості з визначенням прийомів і способів досягнення науково обгрунтованих прогнозів прийнятих нормативних правових актів, спрямованої в кінцевому підсумку на поліпшення їх якості й ефективності [5, с. 47]. Це визначення також є дещо дискусійним, так як окреслюе лише одну із стадій правотворчості як планування, проектування нормативно-правових актів суб'єктами правотворчості.

Висновки та пропозиції. Отже, поряд з категорією «стратегічна правотворчість» дослідники використовують й інші, які, на нашу думку, не розкривають головну сутність та зміст такоі форми правотворчості. Так само, як категорія "стратегічні акти» по-різному трактуеться в науковому середовищі («доктринальні акти», «програмні документи», «концептуальні акти», «акти програмно-директивного характеру», «квазінормативні акти», «стратегічні правові акти») [6-8] тощо. Вважаємо, що саме застосування слова «стратегічний» у визначенні категорій «стратегічна правотворчість» та «стратегічні акти» розкриває їх головний зміст, мету та особливості.
Характерною рисою таких актів та правотворчості $€$ домінування спеціалізованих норм права (норм-принципів, норм-цілей, прогностичних норм, норм-дедрініцій тощо), що закріплюють перспективні цілі й завдання упорядкування та розвитку в різноманітних суспільних й державних сорерах шляхом моніторингу спектру основних проблем у цих сорерах, а також визначають основні напрями, заходи, інституційно-фрункціональний механізм та строки, необхідні для розв'язання цих проблем. Здебільшого в самих стратегічних актах й визначається протягом якого часу слід здійснювати той чи інший крок, тобто вони здебільшого мають строковий характер [9, с. 49].

Відстоюємо позицію, що доречним є виокремлення щонайменше двох основних підходів до трактування категорії «стратегічні акти» та «стратегічна правотворчість»: широкий та вузький. Згідно з першим, «стратегічні акти» охоплюють усі правові акти, що закріплюють перспективні цілі й завдання упорядкування та розвитку в різноманітних суспільних й державних сфрерах шляхом моніторингу спектру основних проблем у цих copepax, a також визначають основні напрями, заходи, інституційно-фрункціональний механізм та строки, необхідні для розв'язання цих проблем: «основи державної політики», «щорічні послання Президента України», «стратегія», «концепція», «доктрина», «програма», «план» тощо. Відповідно до другого, стратегічні акти складають лише ті, що мають назву стратегій (вузький підхід).

Щодо визначення поняття «стратегічна правотворчість", то воно також ідентично до вищезазначеного трактування стратегічних актів має широке та вузьке розуміння як процес підготовки (розроблення), прийняття (ухвалення) чи скасування стратегічних актів (широке та вузьке трактування) уповноваженими органами державної влади, органами місцевого самоврядування чи народом України. Ми є прихильниками широкого наукового підходу, адже нині відсутні достатні напрацювання щодо розрізнення таких актів чи визначення моделі ієрархії між ними. Також негативно впливає й той фракт, що недостатньо нормативно врегульованим $є$ зміст та відмінність між ними. Адже часто-густо попри ідентичні назви стратегічних актів, суб'єкти створення та відповідно чинність таких актів різняться.

Стратегічні акти та стратегічна правотворчість є лише частиною складного понятійно-категоріального ланцюга. Вважаємо конструктивним та перспективним напрямом наукової діяльності визначення та розкриття особливостей, взаємозв'язку, ієрархії цих та інших суміжних за схемою від загального до конкретного: стратегічна правова політика - стратегічна правотворчість - стратегічні акти - стратегічні норми.

\section{Список літератури:}

1. Берназюк I. М. Конституційно-правовий статус та механізми реалізації стратегічних (програмних) актів : автореф. дис. ... д-ра юрид. наук : 12.00.02. Ужкород, 2017. $39 \mathrm{c.}$

2. Макеєва О. М. Доктринальна форма правової політики в умовах правової реформи : матеріали VI міжнар. наук.-практ. конференції (Київ, 26 лютого 2016 року). Тернопіль : Вектор, 206. 384 с.

3. Берназюк I. М. Концептуальні підходи до визначення стратегічної правотворчості. Науковий вісник Міжнародного гуманітарного університету. 2016. № 23. С. 8-10.

4. Голощапов А. М. Конституционные основы становления государственно-правовой стратегии : дис. канд. юрид. наук : 12.00.02. Москва, 2004. $191 \mathrm{c}$.

5. Миронов А. Н. Юридическая стратегия в правотворческой деятельности. Российская юстиция. 2007. № 6. С. $43-47$. 
6. Харченко Н. П. Стратегічні акти в законодавстві України. Держава і право в Уловах глобалізацї: реалії та перспективи : матеріали міжнар. наук.-практ. конф. (Дніпро, 31 січня - 1 лютого 2020 р.). Дніпро, 2020. С. 6-9.

7. Харченко Н. П. Стратегические акты Украины: понятие и особенности. Legea Se Viata. 2020. № 3(339). C. $70-73$.

8. Харченко Н. П. Стратегічні правові акти України. Підприєлниитво, господарство і право. 2020. № 10. С. $242-246$.

9. Харченко Н. П. Стратегічні правові акти в Україні: плюралізм наукових підходів. Прикарпатський юридичний вісник. 2020. Вип. 4. С. 48-51.

\section{References:}

1. Bernazyuk I. M. (2017) Konzeptualnj-pravovii status i mechanism realizazii strategichnih aktiv [Constitutional and legal status and mechanisms for implementing strategic (program) acts]: author's ref. dis. ... Dr. Jurid. Science: 12.00.02. Uzhhorod, $39 \mathrm{p}$.

2. Makeeva O. M. (2016) Doktrinalnaya forma v pravovoi politeke v usloviyah pravovoi reformi [Doctrinal form of legal policy in terms of legal reform]: materials VI International. scientific-practical conference (Kyiv, February 26, 2016). Ternopil: Vector, $384 \mathrm{p}$.

3. Bernazyuk I. M. (2016) Conzeptualnii pidchodi do viznachennya strategichnoi pravotvorchosti [Conceptual approaches to the definition of strategic law-making]. Scientific Bulletin of the International Humanities University, no. 23, pp. 8-10.

4. Goloshchapov A. M. (2004). Konstituzionie osnovi stanovleniya gosudarstvenno- pravovoi strategii [Constitutional foundations of the formation of state-legal strategy]: dis. Cand. jurid. Sciences: 12.00.02. Moscow, $191 \mathrm{p}$.

5. Mironov A. N. (2007) Pravova strategiya v pravotvorchii diyalnosti [Legal strategy in law-making activity]. Russian justice, no. 6, pp. 43-47.

6. Kharchenko N. P. (2020) Strategichni acti v zakonodavstvi Ukraini [Strategic acts in the legislation of Ukraine]. State and law in the context of globalization: realities and prospects: materials intern. scientific-practical conf. (Dnipro, January 31 - February 1, 2020). Dnipro, pp. 6-9.

7. Kharchenko N. P. (2020) Strategichni acti Ukraini : ponyattya ta zmist [Strategic acts of Ukraine: concept and features]. Legea Se Viata, no. 3(339), pp. 70-73.

8. Kharchenko N. P. (2020). Strategichni pravovi acti Ukraini [Strategic legal acts of Ukraine]. Entrepreneurship, economy and law, no. 10, pp. 242-246.

9. Kharchenko N. P. (2020) Strategichni pravovi acti v Ukraini : plyuralizm naukovih pidhodiv [Strategic legal acts in Ukraine: pluralism of scientific approaches]. Prykarpattya Legal Bulletin, vol. 4, pp. 48-51. 